\title{
Potential Export Markets for Bahrain: A Panel Data Analysis
}

\author{
Abdul Waheed and Shujaat Abbas
}

\begin{abstract}
This study investigates export potential of Bahrain with its bilateral trading partners using augmented version of gravity model on panel data of 31 trading partners for the period of 1994 to 2013. The panel generalized least square estimation technique is used to explain macroeconomic behavior of export flows. The results show that the gravity model explain bilateral export flows of Bahrain. Among augmented variables, real exchange rate depreciation and foreign currency reserves of partner countries have significant positive effect on export flows of Bahrain. FTA and GCC dummy have significant positive effect on export flows which shows importance of free trade agreement and Gulf economic integration. The estimation of export potential identified potential markets for exports of Bahrain among selected trading partners. The study urges diversification and development of domestic industries to target potential export markets for economic growth and sustainable development.
\end{abstract}

Index Terms-Export potential, sustainable development, economic integration, gravity model.

\section{INTRODUCTION}

Trade and investment are important factors in economic growth and sustainable development. It is recognized fact that countries can benefit from trading with each other. Currently, however, protectionist policies create barriers to trade and distort markets, resulting in lost opportunities from international trade.

The merchandise exports of Bahrain are highly dependent on few trading partners. The flow of exports toward ten major markets accounts 60 percent of the total export. This shows highly concentrated nature of export flow. The reliance on exports of few commodities and countries results high venerability and dependence of the economy. The trade theories and empirical studies urge achievement of competitive specialization level in diversified exports and markets.

This study aims to identify potential markets for exports of Bahrain. This study first estimate an export flow model and then export potential of Bahrain with its trading partners. It provides framework of market diversification based on

Manuscript received February 3, 2015; revised June 4, 2015.

Abdul Waheed is with University of Bahrain, Kingdom of Bahrain (e-mail: waheedku@yahoo.com).

Shujaat Abbas is with University of Karachi, Pakistan (e-mail: shujaat.abbass@gmail.com). market fundamentals of potential economies or regions.

This paper is divided into five sections. Following introduction, Section II critically reviews the literature, Section III discusses the methodological framework and data sources, Section IV shows estimation results of the model and explores potential export markets. Section V concludes the study with policy implications.

\section{REVIEW OF LITERATURE}

The gravity model describes the most stable relationship in economies, that is, the interactions between the large economies are stronger than that of smaller ones, and close distance economies attract more than of far off. Reference [1] introduced it in empirical analysis of bilateral trade flow. Reference [2] provided theoretical arguments based on quasi-Walsarian model. Reference [3] provided microeconomic foundations based on constant elasticity of substitution (CES) utility function. References [4]-[6] expanded micro-economic foundations of the model by incorporating price term, and explicitly included domestic supply side constraints. 1 The later studies used several dummy variables to capture impact of qualitative variables on bilateral trade flow. The rest of this section discusses some selected applications of the gravity model mostly in Gulf region for the explanation of bilateral trade.

The empirical literature shows some notable studies attempted to address bilateral trade flow of Gulf countries. Reference [7] investigated trade flow of GCC countries within the intra Arab and outside the region. The expected level of trade in the region is investigated using the gravity model. The traditional gravity model is augmented by dummy for region, language, common border, trade openness and Arab countries. The model is estimated using panel least square estimation technique and the result shows that the gravity model explains intra Arab trade quite well. The intra Arab trade is positively determined by GDPs and negative determine by the bilateral distance. The findings show that the actual intra Arab trade is significantly lower than predicted, indicating considerable scope for multilateral economic integration, especially regional one.

Reference [8] investigated whether Turkey has any special trade relationship with European Union using the gravity model of international trade, with balance panel data of 45 countries (cross sections) for the period of 1965-2011. The data set comprises 1575 entries for each observation. The dependent variable is merchandise export or import of Turkey. The traditional gravity equation is augmented by the addition of both qualitative and quantitative variables such as

${ }^{1}$ For theoretical foundation of the gravity model of international trade, see Reference [15] 
a customs union, European Union and bilateral trade agreements. The parameters are estimated using panel fixed effect estimation technique. The result shows that the gravity model explains the behavior of turkey's merchandise trade flow.

Reference [9] investigated inter and intra-regional trade potential of Gulf Cooperative Council (GCC), with major trading partners using augmented gravity model. The result shows that although inter GCC trade is small in absolute term, it is actually higher than expected. The trade agreement of GCC countries, with European Union and USA is found to have trade promising effect. The author suggested greater economic integration through bilateral and multilateral agreements.

Reference [10] investigated whether Gulf Cooperative Council exert any trade enhancing impact on member countries, using standard gravity model and stochastic frontier gravity model from 1980 to 2008 . The finding shows significant trade enhancing effect of GCC block. The author also observed huge unutilized trade potential among member countries and urges proper utilization of potential through greater economic integration.

Reference [11] investigated impact on bilateral trade flow of GCC countries before and after formation of custom union in 2003, using augmented gravity model. The panel least square and generalized method of movement (GMM) techniques are used to estimate the models. The result shows that integration of gulf countries has not fostered the intra-GCC trade except in UAE. The trade pattern has shifted from European and US to Asian countries after 2003, and trade flow of GCC is correlated with wealth of trading partners, but not distance. The distance is important concept in gravity model. It proxies all trade distorting factors, which cannot be ignored.

Reference [12] addressed two aspects of intra GCC tradeflow of goods and services and the oil. Firstly, the author assesses intra GCC trade flow based on the nature of good and services transacted, that is oil flow and non-oil flow. Secondly, the author investigated determinants of trade of both categories by gravity model in panel framework for the period of 2007, 2008, and 2009. The standard gravity equation is augmented by incorporating quality of infrastructure (road, air transport, port efficiency and telecommunication). The parameters are estimated using fixed effect estimation technique and the result shows that gravity model explains intra GCC trade flow. The findings show significantly higher effect of infrastructure development on trade flow of Gulf countries, and the study urges development of advance infrastructure.

Reference [13] investigated trade flow and potential of India with 146 countries using gravity model on cross sectional data of 2005. The findings show that the trade flow of India is positively determined by income level, distance, geographical and cultural factors. The study concludes highest trade potential with China, UK, Italy, and France. It found highest trade potential of India with Pakistan in SAARC, and Cambodia and Philippines in ASEAN.

In a recent study [14], we investigated export potential of Pakistan with 40 bilateral trading partners using the augmented gravity model on panel framework. The result shows that export flow of Pakistan is positively related to domestic income, population and income of the partners, whereas negatively related to distance. The result shows that Pakistan has exhausted its potential with major trading partners, whereas higher potential is observed in other developed countries in Europe and North America, and developing regional emerging economies, such as China, India and Brazil. The study suggested need for development of important production sectors and diversification of composition and flow of exports for the achievement of sustainable economic growth.

\section{MethodologicAl FRAMEWORK}

\section{A. Modeling Export Flow}

The standard gravity model introduced by [1] argues that bilateral trade flow is positive function of economic size and negative function of distance. The current study is based on gravity model but augmented by inclusion of other qualitative and quantitative variables to address bilateral export flow of Bahrain. The augmented gravity model is expressed as follows:

$$
\begin{aligned}
& \log \left(X_{i j t}\right)=\beta_{0}+\beta_{1} \log \left(Y_{i t}\right)+\beta_{2} \log \left(Y_{j t}\right)+\beta_{3} \log \left(D_{i j}\right) \\
&+\beta_{4} \log \left(R E R_{i j t}\right)+\beta_{5} \log \left(P O P_{j t}\right) \\
&+\beta_{6} \log \left(F C R_{j t}\right)+\beta_{7} \mathrm{GCC}+\beta_{8} C L A N G+\beta_{9} F T A+\omega_{i t}
\end{aligned}
$$

where $X_{i j t}$ is bilateral export flow of Bahrain represented by country $(i)$ to trading partner country $(j), Y_{i t}$ is domestic income level, $Y_{j t}$ is foreign income level, $D_{i j}$ is the distance between capital cities and measured in kilometers. Distance is generally accepted as proxy for transportation cost. $R E R_{i j t}$ is the bilateral real exchange rate. $P O P_{j t}$ is the population of the trading partner country. $F C R_{j t}$ is the foreign currency reserve of the partner country. GCC is the dummy for Gulf Cooperation Council, CLANG is the common language dummy and FTA is the dummy for free trade agreement of Bahrain with USA. The composite error term is $\omega_{i t}$. As per standard gravity model $\beta_{1}$ and $\beta_{2}$ are expected to be positive while $\beta_{3}$ is expected to be negative. The parameters for augmented variables $\beta_{4}$ to $\beta_{9}$ are expected to be positive.

$$
R E R_{i j t}=E R_{i j t}\left(P_{j t} / P_{i t}\right)
$$

where $E R_{i j t}$ is the bilateral nominal exchange rate, $P_{j t}$ is price level of trading partner and $P_{i t}$ is domestic price level.

\section{B. Estimation of Export Potential}

The difference between predicted and actual bilateral export flow is used to investigate the existence of export potential. Following [16] the export potential is estimated as follows:

$$
X P_{i j t}=\frac{\sum \bar{E}_{i j t}}{\sum E x_{i j t}}
$$


where $X P_{i j t}$ is export potential, $\sum \overline{E x}_{i j t}$ is the predicted export flow, $\sum E x_{i j t}$ is the actual export flow. The value of index greater than 1 indicates that the actual export flow is less than predicted flow, indicating untapped export potential. Whereas the value of index less than 1 indicates that the actual export flow is greater than the predicted flow, indicating exhausted export potential.

\section{ESTIMATION RESULTS}

The macroeconomic behavior of export flow of Bahrain to its trading partners is investigated by constructing panel data of 31 cross-sectional units from 1994 to 2013. The sample is drawn from 31 important global trading partners including top ten export markets and GCC countries.
TABLE I: DETERMINANTS OF EXPORT FLOW

\begin{tabular}{|c|c|c|c|}
\hline \multirow{2}{*}{$\begin{array}{c}\text { Explanatory } \\
\text { Variables }\end{array}$} & \multicolumn{3}{|c|}{ Dependent Variable: Log (Xij) } \\
\cline { 2 - 4 } & Coeff. & t-stat. & p-value \\
\hline Constant & -7.484 & -10.156 & 0.000 \\
\hline $\log ($ Yi $)$ & 0.761 & 13.999 & 0.000 \\
\hline $\log (Y j)$ & 0.212 & 5.460 & 0.000 \\
\hline $\log (\mathrm{Dij})$ & -0.146 & -2.383 & 0.018 \\
\hline $\log (\mathrm{RERij})$ & 0.085 & 5.179 & 0.000 \\
\hline $\log (\mathrm{POPj})$ & 0.273 & 8.192 & 0.000 \\
\hline $\log (\mathrm{FCRj})$ & 0.137 & 3.680 & 0.000 \\
\hline GCC & 3.430 & 12.718 & 0.000 \\
\hline CLANG & -1.401 & -6.106 & 0.000 \\
\hline FTA & 0.835 & 1.977 & 0.049 \\
\hline \multicolumn{2}{|c|}{} & Adjusted R & 0.957 \\
\hline Total Panel obs. & 620 & Bias Proportion & 0.025 \\
\hline Cross Sections & 31 & $\begin{array}{c}\text { Variance } \\
\text { Proportion }\end{array}$ & 0.002 \\
\hline $\begin{array}{l}\text { S.E. of } \\
\text { regression }\end{array}$ & 1.196 & & \\
\hline
\end{tabular}

TABLE II: BAHRAIN'S GLOBAL EXPORT POTENTIAL

\begin{tabular}{|c|c|c|c|c|c|c|c|}
\hline Trading Partners & 1994-00 & 2001-06 & $2007-13$ & Trading Partners & 1994-00 & 2001-06 & $2007-13$ \\
\hline$\underline{\text { ASIA }}$ & & & & Thailand & 1.09 & 0.908 & 0.974 \\
\hline$\underline{\text { East Asia }}$ & & & & $\underline{\text { AFRICA }}$ & & & \\
\hline China & 1.461 & 1.333 & 1.209 & Egypt & 1.147 & 3.232 & 0.732 \\
\hline Japan & 0.866 & 0.966 & 0.956 & S. Africa & 5.438 & 1.487 & 0.796 \\
\hline Korea & 0.749 & 0.868 & 0.874 & Kenya & 1.149 & 0.656 & 0.799 \\
\hline South Asia & & & & $\underline{\text { EUROPE }}$ & & & \\
\hline India & 0.836 & 1.051 & 0.949 & Turkey & 0.715 & 1.292 & 1.120 \\
\hline Pakistan & 0.849 & 1.040 & 0.955 & Italy & 1.340 & 1.030 & 0.978 \\
\hline Sri Lanka & 2.210 & 1.580 & 4.695 & France & 1.887 & 0.984 & 0.923 \\
\hline$\underline{\text { Gulf Countries }}$ & & & & United Kingdom & 0.972 & 0.814 & 1.133 \\
\hline Saudi Arabia & 0.951 & 1.027 & 1.034 & Germany & 1.651 & 1.218 & 1.376 \\
\hline Kuwait & 0.954 & 1.067 & 1.083 & Belgium & 1.234 & 0.931 & 1.621 \\
\hline Oman & 1.180 & 0.961 & 0.979 & Netherlands & 0.998 & 0.991 & 0.744 \\
\hline Qatar & 0.958 & 1.095 & 1.063 & Denmark & 1.455 & 0.687 & 1.837 \\
\hline UAE & 0.988 & 0.957 & 0.977 & Norway & 3.596 & 0.835 & 0.965 \\
\hline$\underline{\text { South-East Asia }}$ & & & & $\underline{\text { AMERICA }}$ & & & \\
\hline Philippines & 0.742 & 1.965 & 1.865 & USA & 0.844 & 0.841 & 1.017 \\
\hline Malaysia & 0.809 & 0.831 & 0.851 & Canada & 2.374 & 1.796 & 2.597 \\
\hline Singapore & 0.564 & 0.632 & 0.690 & & & & \\
\hline Indonesia & 1.197 & 1.288 & 1.264 & $\underline{\text { AUSTRALIA }}$ & 3.596 & 0.835 & 0.965 \\
\hline
\end{tabular}

The annual time series data of export flow is taken from Direction of Trade Statistic (DOTS) of International Monetary Fund ${ }^{2}$. The data of GDP, GDP deflators and population are taken from World Development Indicators (WDI) of the World Bank. The data of foreign currency reserve are taken from International Financial Statistics (IFS) of the International Monetary Fund. The data of bilateral distance is collected from Centre d'Etudes Prospectives et d'informations internationales (CEPII). ${ }^{3}$. The data of bilateral exchange rate of Bahrain is not available in secondary data sources. It is calculated from official exchange rates of individual countries, collected from WDI. References [16]

${ }^{2}$ http://elibrary-data.imf.org/

${ }^{3}$ French Research Centre in International Economics http://www.cepii.fr/ use consumer price index (CPI) to represent the price level. Reference [10] suggested that the GDP deflator can be used in case CPI data is not available. We used GDP deflator as price indicator and its data is taken from WDI. The dummy variable for GCC countries is generated as valuing 1 for GCC countries such as Saudi Arabia, United Arab Emirates, Kuwait, Oman and Qatar otherwise 0. Similarly dummy for common language and FTA with USA are generated. ${ }^{4}$

\section{A. Determinants of Export Flow}

The macroeconomic behavior of bilateral export flow of Bahrain with its major 31 bilateral trading partners for the period of 1994 to 2013 is investigated using panel

${ }^{4}$ Bahrain became USA's first partner in the Arabian Peninsula with the enforcement of the USABFTA on August 1, 2006. 
Generalized Least Square (GLS) method with cross sectional weight. The results are reported in Table I.

The results show that both $Y_{i t}$ and $Y_{j t}$ has significant positive effect on bilateral export flow of Bahrain with its trading partners. The export flow is more sensitive to domestic income than foreign income. The coefficient of distance is negative but the elasticity is low. The bilateral real exchange rate's elasticity has been found to have positive and highly significant. Thus a depreciation of Bahraini dinar would result higher export flow to its trading partners. The coefficient of partners' population and foreign currency reserves variables are positive and highly significant. The dummy variable of GCC and FTA with USA are positive and statistically significant while common language dummy is negative and statistically significant.

The log linear model is used to address problem of serial correlation and hetroscedasticity in the regression model. The adjusted $R^{2}$ indicates that 95.7 percent variations in export flow of Bahrain is explained by these nine variables that are included in the model as explanatory variables. The bias and variance proportion of the model are very low indicating that model is fit for forecasting.

\section{B. Export Potential}

This section discusses result of export potential of Bahrain with its bilateral trading partners using the estimation results of augmented gravity model reported in Table I. The result of potential export markets for Bahrain is presented in Table II.

The results show that Bahrain has exceeded its export potential with its East and South Asian trading partners such as Japan, Korea, India, and Pakistan except China and Sri Lanka. Among Gulf countries it has exceeded its export potential with Oman and UAE. There is still potential for export to Saudi Arabia, Kuwait and Qatar. In South East Asia, the exhausted export potential is observed with Malaysia, Singapore and Thailand but there is higher export potential with Philippine and Indonesia. Bahrain exhausted its export potential with selected African countries and Australia. Bahrain has significantly higher export potential with most of the European countries except Italy, France, Netherland and Norway. There is still export potential with USA and Canada.

\section{CONCLUSION AND POLICY IMPLICATIONS}

This study investigates macroeconomic determinants of bilateral export flow and estimate export potential of Bahrain with its major trading partners using augmented version of gravity model on panel data of 31 countries for the period 1994 to 2013.

The panel generalized least square estimation technique is used to estimate the model that explains major determinants of export flow of Bahrain with its trading partners. The results show that the gravity model explains bilateral trade flow of Bahrain and findings are consistent with the model arguments. The diagnostic test confirmed model accuracy and efficiency. It is found that higher growth is necessary for higher exports. Furthermore, a real depreciation would make Bahraini product cheaper for its trading partners therefore a depreciated real exchange rate promote export flows. The dummy for GCC shows significant positive impact on bilateral trade flows that indicating trade creating effect of Gulf economic integration. The result indicates that Bahrain FTA with USA has positive impact on its export flows.

The policy implications for this study are that Bahrain needs to depreciate its currency, has to go for more free trade agreements and develop the domestic industries targeting markets of potential economies for expansion in its exports.

\section{REFERENCES}

[1] J. Tinbergen, Shaping the World Economy, New York: Twentieth Century, 1962

[2] H. Linnemann, An Econometric Study of International Trade Flows, Amsterdam: North-Holland, 1966.

[3] J. Anderson, "A theoritical foundation for the gravity equation," The American Economic Review, vol. 69, no. 1, pp. 106-116, 1979.

[4] J. H. Bergstrand, "The gravity equation in international trade, some microeconomic foundations and empirical evidence," Review of Economics and Statistics, vol. 67, pp. 474-481, 1985.

[5] J. H. Bergstrand, "The generalized gravity equation, monopolistic competition, and the factor-proportions theory in international trade," The Review of Economics and Statistics, vol. 71, no. 1, pp. 143-153, 1989.

[6] J. H. Bergstrand, "The heckscher-ohlin-samuelson model, the linder hypothesis and the determinants of bilateral intra-industry trade," The Economic Journal, vol. 100, no. 403, pp. 1216-1229, 1990.

[7] H. Al-Atrash and T. Yousef, "Intra-Arab trade: Is it too late?" IMF Working Paper 00/10, Washington, DC: International Monetary Fund, 2000 .

[8] D. Antonucci and S. Manzocchi, "Does turkey have a special trade relation with the EU? A gravity model approach," Economic Systems, vol. 30, pp. 157-169, 2005.

[9] H. Boughanmi, "The trade potential of the Arab Gulf cooperation countries (GCC): A gravity model approach," Journal of Economic Integration, vol. 23, pp. 42-56, 2008.

[10] R. A. Salim, M. A. Kabir, and N. AlMawali, "Does more trade potential remain in Arab States of the Gulf?" Journal of Economic Integration, vol. 26, no. 2, pp. 217-243, 2011.

[11] A. Insel and M. Tekce, "Bilateral trade flows in the Gulf cooperation council countries: What happened to the Middle East integration after 2003?" Journal of Economic Integration, vol. 26, no. 2, pp. 244-275, 2011.

[12] S. Nechi, "Determinants of trade flows among GCC countries: Potentials, limitations, and expectations," World Review of Business Research, vol. 1, no. 5, pp. 91-109, 2011.

[13] A. Batra, "India's global trade potential: The gravity model approach," Global Economic Review, vol. 35, no. 3, pp. 327-361, 2006.

[14] S. Abbas and A. Waheed, "Pakistan's potential export flow: The gravity model approach," Journal of Developing Areas, 2015.

[15] P. A. Bergeijk and S. Brakman, The Gravity Model in International Trade; Advance and Applications, New York: Cambridge University Press, 2010.

[16] J. Burn, C. Carrere, P. Guillaumont, and J. Melo, "Has distance died? Evidence from a panel gravity model," World Bank Economic Review, vol. 19, no. 1, pp. 99-120, 2005.

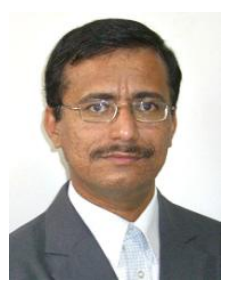

Abdul Waheed was born in Pakistan on November 21,1968 . He is an economist with expertise in international development and specializes in economic issues of South Asia. Dr. Waheed achieved the Ph.D. degree in international development from Nagoya University, Japan, under Japanese government Monbusho fellowship in March 2005, and successfully completed the post doctorate research under Japan Society for the Promotion of Science (JSPS) fellowship in September 2006. He earned his B.Sc. (Hons.), M.Sc. and M.A.S degrees in economics from University of Karachi with more than 3.5 GPA on scale 4. Dr. Waheed was invited as a guest speaker by the Government of South Korea in October 2007 to make a presentation on "Financial social accounting matrix of Pakistan" constructed by him during his post doc research. The Institute of Developing Economies also invited him to Tokyo, Japan in 2009 as a visiting research fellow, to conduct research on "Financial Sector Reforms in Pakistan". He has more than twenty years' experience in teaching and research at university level including ten years post Ph.D. experience. 
During the last twenty years he has had the opportunity to teach various courses at graduate and post graduate levels in different educational institutions. He has been participating in a wide variety of research projects. As an outcome of his research activities, he has twenty-one scholarly contributions in peer reviewed academic journals, a chapter in a book and a monograph. He participated in many international conferences and workshop held in different countries. He has been the chairman of the Department of Economics, Member Senate, Academic Council, and Board of Governors AERC, at University of Karachi. Currently he is the associate professor at the Department of Economics \& Finance, College of Business Administration, University of Bahrain, Kingdom of Bahrain.

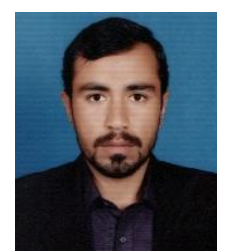

Shujaat Abbas was born in Pakistan on September 1, 1988. He got the MBA in finance from Federal Urdu University and MS degree in economics from University of Karachi. Currently he is a $\mathrm{Ph} . \mathrm{D}$. candidate in economics at the Department of Economics, University of Karachi, and working on International trade and economic development under the supervision of Dr. Abdul Waheed. His areas of research interest are economic development issues, especially related to developing countries. He has scholarly contributions in peer reviewed academic journals and has teaching experience at University of Karachi, Pakistan. 